\title{
PERILAKU IBU YANG MEMILIKI BALITA DALAM PEMANFAATAN POSYANDU DI KAMPUNG SRI GADING KECAMATAN LUBUK DALAM KABUPATEN SIAK TAHUN 2018
}

\author{
Andalia Roza ${ }^{1 *}$, Multi Safriyatun ${ }^{2}$, Lora Marlita ${ }^{3}$ \\ 1,2,3, Fakultas Ilmu Kedokteran dan Ilmu Kesehatan, Universitas Abdurrab \\ *Email: andalia.roza@univrab.ac.id
}

\begin{abstract}
Posyandu is one form of UKBM (Community Based Health Effort) is best known by the community. Health behavior is a response of a person (organism) to stimuli or objects related to Knowledge (Knowlegde), Attitude (attitude), and action. The purpose of this study is to find out the description of the behavior of mothers who have a toddler in the utilization of posyandu dikampung srigading Kecamatan Lubuk Dalam Siak regency. The type of this research is descriptive by using random sampling technique. The research instrument used questionnaire. Respondents of this research mother who has a toddler in Kampung Sri Gading Kecamatan Lubuk In Siak regency as many as 60 respondents. This study was conducted on June 10 to June 28, 2018. The results of this study in general knowledge level in mothers who have a toddler in the category Good as many as 59 people (98.34\%), Enough as much as 1 person (1.67\%) and Less as much 0 people (0\%). The results of this study in general about attitudes in mothers who have toddlers can be categorized Positive as many as 51 people (85\%), Negative as many as 9 people (15\%). The results of this study in general about the action on mothers with toddlers can be categorized Good as many as 53 people (88.34\%), Not Good as many as 7 people (11.67\%). Based on the results of general research on knowledge of mothers who have a toddler in pemgunan posyandu in good category, that is as much as 59 people $(98,34)$. About the attitude of mother who has toddler in posyandu utilization in positive category, that is 51 people (85\%). About the actions of mothers who have children under five in the use of posyandu in good category, that is as many as 53 people (88.34\%). It is expected that mothers with toddlers to improve the posyandu activities again.
\end{abstract}

Keywords $\quad$ : Behavior, Utilization of Posyandu

\begin{abstract}
ABSTRAK
Posyandu merupakan salah satu bentuk UKBM (Upaya Kesehatan Bersumberdaya Masyarakat) yang paling dikenal oleh masyarakat.Perilaku kesehatan adalah suatu respon seseorang (organisme) terhadap stimulus atau objek yang berkaitan dengan Pengetahuan (knowlegde), Sikap (attitude), dan tindakan (practice).Tujuan penelitian ini adalah untuk mengetahui gambaran perilaku ibu yang memiliki balita dalam pemanfaatan posyandu dikampung srigading Kecamatan Lubuk Dalam Kabupaten Siak. Jenis penelitian ini adalah deskriptif dengan menggunakan teknik penelitianRandom Sampling. Instrumen penelitian menggunakan kuesioner. Responden penelitian ini Ibu yang memiliki balita di Kampung Sri Gading Kecamatan Lubuk Dalam Kabupaten Siak sebanyak 60 responden. Penelitian ini dilakukan pada tanggal 10 Juni - 28 Juni 2018. Hasil penelitian ini secara umum tingkat pengetahuan pada ibu yang memiliki balita dalam kategori Baik sebanyak 59 orang $(98,34 \%)$, Cukup sebanyak 1 orang $(1,67 \%)$ dan Kurang sebanyak 0 orang $(0 \%)$.Hasil penelitian ini secara umum tentang sikap pada ibu yang memiliki balita dapat dikategorikan Positif sebanyak 51 orang (85\%), Negatif sebanyak 9 orang (15\%). Hasil penelitian ini secara umum tentang tindakan pada ibu yang memiliki balita dapat dikategorikan Baik sebanyak 53 orang $(88,34 \%)$, Tidak Baik sebanyak 7 orang $(11,67 \%)$. Berdasarkan hasil penelitian secara umum tentang pengetahuan pada ibu yang memiliki balita dalam pemanfaatn posyandu dalam kategori baik, yaitu sebanyak 59 orang $(98,34)$. Tentang sikap ibu yang memiliki balita dalam pemanfaatan posyandu dalam kategori positif, yaitu sebanyak 51 orang (85\%). Tentang tindakan pada ibu yang memiliki balita dalam pemanfaatan posyandu dalam kategori baik, yaitu sebanyak 53 orang $(88,34 \%)$.Diharapkan kepada ibu yang memiliki balita untuk meningkatkan lagi kegiatan posyandu.

Kata Kunci : Perilaku, Pemanfaatan Posyandu
\end{abstract}




\section{PENDAHULUAN}

Posyandu merupakan salah satu bentuk UKBM (Upaya Kesehatan Bersumberdaya Masyarakat) yang paling dikenal oleh masyarakat. Posyandu menyelenggarakan minimal 5 program prioritas, yaitu kesehatan ibu dan anak, keluarga berencana, perbaikan gizi, imunisasi, dan penanggulangan diare. Posyandu merupakan salah satu sarana pelayanan kesehatan promotif dan preventif. Dimana masalah gizi pada balita dapat diketahui lebih awal dengan peningkatan berat badan anak balita sebagai indikatornya yang dapat diketahui melalui posyandu.(Depkes RI,2011).

Posyandu adalah suatu bentuk keterpaduan pelayanan kesehatan yang dilaksanakan disuatu wilayah kerja posyandu, dimana pelaksanaanya dilakukan ditiap kelurahan/RW. Posyandu diselenggarakan setiap bulan sekali untuk masyarakat yang dibantu oleh petugas kesehatan setempat (Depkes RI,2011).

Kegiatan Posyandu diasumsikan sebagai salah satu pendekatan yang tepat untuk menurunkan angka kematian dan kesakitan balita serta dapat meningkatkan status gizi balita. Kegiatan posyandu pada balita meliputi Penimbangan berat badan, Penentuan status pertumbuhan, Penyuluhan, Pemeriksaan kesehatan sedini mungkin. Pentingnya keberadaan Posyandu di tengah masyarakat yang merupakan pusat kegiatan masyarakat dimana masyarakat sebagai pelaksana sekaligus memperoleh pelayanan kesehatan serta keluarga berencana, selain itu wahana ini dapat dimanfaatkan sebagai sari 1 tukar menukar informasi (Depkes

Bardasarkan hasil pene muanyanz dilakukan di Nigeria tahun 2011 kurangnya pemanfaatan posyandu yaitu menunjukkan bahwa 23,6 \% anak stunting, dan 22,0\% anak gizi kurang. Penelitian didaerah kumuh perkotaan Bhubaneswar Odisha
India, melibatkan anak-anak dari kelompok usia (3-9 tahun) selama tahun 2013-2014, hasil penelitiannya yaitu $57,4 \%$ anak stanting, dan 45,4 \% anak gizi kurang. Analisis menunjukkan bahwa faktor-faktor penentu signifikan dari gizi buruk adalah jenis kelamin dan usia anak, pendidikan dan indeks massa tubuh ibu, asupan kalori dari rumah tangga, akses keair dan keberadaan toilet rumah tangga (Olanrewaju dkk,2011).

Di Indonesia angka pemanfaatan posyandu oleh ibu masih rendah ini dibuktikan lebih kurang 280.225 posyandu di Indonesia hanya $40 \%$ yang masih aktif (Riskesdes, 2013).

Di Sumatra di dapati pemanfaatan posyandu masih dibawah standart ketentuan yang berlaku. Didapati presentase balita yang memliki imunisasi lengkap hanya sekitar $60,9 \%$, balita yang tidak memiliki imunisasi lengkap sebesar $36,7 \%$, dan balita yang tidak sama sekali mendapati imunisasi sekitar 2,3\%.(Depkes RI, 2011).

Posyandu aktif di Provinsi Riau pada tahun 2012 adalah sebesar 44,37\% sedangkan pada tahun 2013 posyandu aktif mengalami penurunan menjadi $43,78 \%$ sehingga revitalisasi posyandu masih perlu mendapat perhatian dari semua sektor/pihak terkait (Profil Kesehatan Provinsi Tahun 2013).

Dampak yang dialami balita, bila ibu balita tidak aktif dalam kegiatan posyandu antara lain tidak mendapatkan penyuluhan kesehatan tentang pertumbuhan balita yang normal, tidak mendapat vitamin A untuk kesehatan mata, ibu balita tidak mengetahui pertumbuhan berat badan balita tiap bulan, ibu balita tidak mendapatkan pemberian dan penyuluhan tentang makanan tambahan (PMT), dengan aktif dalam kegiatan posyandu ibu balita dapat memantau tumbuh kembang balitanya (Depkes RI, 2011). 
Perilaku kesehatan menurut Notoatmodjo (2011) adalah suatu respon seseorang (organisme) terhadap stimulus atau objek yang berkaitan dengan Pengetahuan (knowlegde), Sikap (attitude), dan Praktik atau tindakan (practice). Pengetahuan adalah hasil dari tahu, dan ini terjadi setelah seseorang melakukan penginderaan terhadap suatu objek tertentu. Tanpa pengetahuan seseorang tidak mempunyai dasar untuk mengambil keputusan dan menentukan tindakan terhadap masalah yang dihadapi. Sikap merupakan reaksi atau respon yang masih tertutup dari seseorang terhadap suatu stimulus atau objek. Suatu sikap belum otomatis terwujud dalam suatu tindakan (overt behavior). Untuk mewujudkan sikap menjadi suatu perbuatan yang nyata diperlukan faktor pendukung atau suatu kondisi yang memungkinkan, antara lain adalah fasilitas dan faktor dukungan (support).

Faktor-faktor

yang

mempengaruhi perilaku ibu balita dalam pemanfaatan posyandu yaitu: Factor Predisposing dengan Hasil penelitian hubungan factor Predisposingyang meliputi pendidikan ibu, pekerjaan ibu pengetahuan ibu dan sikap ibu dengan tingkat partisipasi ibu dalam penimbangan balita ke posyandu di Wilayah Kerja Puskesmas. Hasil analisis bivariat menunjukkan bahwa Tingkat Partisipasi ibu antara ibu yang berpendidikan tinggi dan ibu yang berpendidikan rendah sebanyak $(59,3 \%)$ dan $(63,2 \%)$ tingkat partisipasinya masih kurang. Tidak ada perbedaan yang signifikan antara ibu yang berpendidikan tinggi dan rendah dengan tingkat partisipasi ibu dalam penimbangan balita ke posyandu karena tingkat partisipasi masih sama-sama rendah (Darussalam Kecamatan Medan Petisah Tahun 2013). Hasil analisis bivariat menunjukkan bahwa Tingkat Partisipasi ibu antara ibu yang bekerja dan tidak bekerja sebanyak $(53,3 \%)$ dan $(61,9 \%)$ tingkat partisipasinya masih kurang (Darussalam Kecamatan Medan Petisah Tahun 2013).

Faktor lain yaitu: terbatasnya pengetahuan, sikap dan tindakan ibu untuk membawakan anak balitanya ke posyandu. Hasil analisis Bivariat menunjukan hanya $18,2 \%$ ibu yang berpengetahuan kurang tingkat partisipasi sudah baik. Sedangkan ibu yang berpengetahuan baik ada 56,3\% yang tingkat partisipasinya sudah baik. Hasil analisis Bivariat menunjukan 57,6\% ibu yang bersikap baik tingkat partisipasinya sudah baik, sedangkan diantara ibu yang bersikap kurang hanya 23,1\% tingkat partisipasinya baik.

Factor Reinforcing dengan Hasil penelitian hubungan factor Reinforcing yang meliputi sikap kaderdan sikap keluarga ibu dengan tingkat partisipasi ibu dalam penimbangan balita ke posyandu di Wilayah Kerja Puskesmas Darussalam Kecamatan Medan Petisah Tahun 2013. Hasil analisis Bivariat menunjukkan 49,1\% ibu yang mendapat dukungan dari kader posyandu.

Menurut Hindu dkk,2013 terdapat penelitian dikabupaten Sragen yaitu untuk keaktifan ibu menimbangkan balita keposyandu sebagian besar tidak aktif sebanyak 52,4\%. DKI Jakarta etimasi jumlah balita pada tahun 2013 sebanyak 863,999 dari jumlah tersebut hanya 179,887 balita ditimbang terdapat selisih 684,112 balita yang memiliki kemungkinan tidak terdeteksi balita gizi buruk atau gizi kurang (kemenkes RI, 2013)

Berdasarkan hasil survei yang telah dilakukan di Kampung Sri Gading tahun 2017 dengan menggunakan teknik wawancara dan observasi. Dengan mewawancarai petugas yang bekerja diposyandu yang dibawah wewenang Puskesmas Lubuk Dalam diketahui bahwa kesadaran ibu-ibu untuk membawa balitanya keposyandu masih kurang. 
Dikampung Sri Gading terdapat 1 posyandu, dengan jumlah keseluruhan balita sebanyak 130 dan yang rutin datang ke posyandu sebanyak 5 balita. Hasil wawancara dengan 10 ibu balita yang tidak membawa balitanya ke posyandu karena sibuknya pekerjaan yang dilakukannya, usia balitanya sudah lebih dari 12 bulan, anak yang sudah mulai sekolah, ada beberapa ibu juga yang tidak mau anaknya diimmunisasi dengan alasan anaknya mengalami demam setelah diimunisasi.

Dari latar belakang diatas maka peneliti ingin mengetahui perilaku ibu yang memiliki balita dalam pemanfaatan posyandu Kampung Sri Gading Kecamatan Lubuk Dalam Kabupaten Siak.

Tujuan umum dari penelitian ini adalah untuk mengetahui gambaran perilaku ibu yang memiliki balita dalam pemanfaatan posyandu dikampung srigading Kecamatan Lubuk Dalam Kabupaten Siak. Yang diperinci dengan Tujuan Khusus sebagai berikut :

1. Mendeskripsikan pengetahuan tentang ibu yang memiliki balita keposyandu kampung srigading.

2. Mendeskripsikan sikap tentang ibu yang memiliki balita keposyandu kampung srigading.

3. Mendeskripsikan tindakan tentang ibu yang memiliki balita keposyandu kampung srigading.

\section{METODE PENELITIAN}

Jenis penelitian ini adalah penelitian kuantitatif non eksperimental dengan design penelitian deskriptif.

Penelitian ini yang akan dilakukan di Kampung Srigading Kecamatan Lubuk Dalam Kabupaten Siak. Penelitian dilaksanakan pada bulan Maret 2018.

Populasi dalam penelitian ini adalah semua ibu yang memiliki balita dalam pemanfaatan posyandu di Kampung Srigading Kecamatan Lubuk Dalam
Kabupaten Siak yaitu 70 orang. Teknik pengambilan sampel pada penelitian ini dengan menggunakan teknik Random Sampling dengan mempertimbangkan kriteria inklusi dan ekslusi dengan jumlah sampel 60 sampel.

Pengumpulan data dilakukan dengan cara wawancara kepada ibu yang memiliki balita dalam pemanfaatan posyandu dengan menggunakan kuesioner.

Pengelolaan data merupakan suatu proses untuk memperoleh data atau data ringkasan berdasarkan suatu kelompok data mentah dengan menggunakan rumusan teretentu sehingga menghasilkan informasi yang diperlukan (Setiadi,2007). Dan beberapa kegiatan dalam pengolahan data yaitu sebagai berikut :Editing,Coding, Entry dan Tabulating.

Analisa data yang digunakan adalah analisa univariat dengan bantuan SPSS.

\section{HASIL DAN PEMBAHASAN Hasil penelitian}

Hasil penelitian yang dilakukan pada tanggal 10 Junis.d 28 juni 2018 dengan jumlah responden60orang dengan menggunakan kuesioner di Kampung Sri Gading Kecamatan Lubuk Dalam Kabupaten Siak untuk mengetahui Perilaku Ibu yang Memiliki Balita dalam Pemanfaatan Posyandu Di Kampung Sri Gading Kecamatan Lubuk Dalam Kabupaten Siak dapat dilihat pada tabeltabel sebagai berikut :

\section{Data umum}

Distribusi Frekuensi Berdasarkan Umur Ibu yang Memiliki Balita Dalam Pemanfaatan Posyandu Di Kampung Sri Gading Kecamatan Lubuk Dalam Kabupaten Siak Tahun 2018 adalah umur 20-30 Tahun : $19(31,67 \%)$ dan umur 31-40 Tahun: 41 (68,34\%).

Distribusi Frekuensi Berdasarkan Pendidikan Ibu yang Memiliki Balita Dalam 
Pemanfaatan Posyandu Di Kampung Sri Gading Kecamatan Lubuk Dalam Kabupaten Siak Tahun 2018 adalah SD : 9(15\%), SMP: 16 (26,67\%), SMA: 27 (45\%) dan perguruan tinggi : $8(13,34 \%)$.

Distribusi Frekuensi Berdasarkan Pekerjaan Ibu yang Memiliki Balita Dalam Pemanfaatan Posyandu Di Kampung Sri Gading Kecamatan Lubuk Dalam Kabupaten Siak Tahun 2018 adalah IRT : 47 $(78,34 \%)$, Petani : 1 (1,67\%), Guru : 9 (15\%) dan Wiraswasta : $3(5 \%)$.

Distribusi Frekuensi Berdasarkan Informasi Ibu yang Memiliki Balita Dalam Pemanfaatan Posyandu Di Kampung Sri Gading Kecamatan Lubuk Dalam Kabupaten Siak Tahun 2018 adalah yang sudah mendapatkan informasi sebanyak 60 responden (100\%) dengan rincian : pelayanan kesehatan 11 responden $(18,34 \%)$, petugas puskesmas 48 responden (80\%), dan Majalah/Koran 1 (1,67\%).

\section{Data khusus}

Distribusi Frekuensi Pengetahuan Ibu yang Memiliki Balita Dalam Pemanfaatan Posyandu Di Kampung Sri Gading Kecamatan Lubuk Dalam Kabupaten Siak Tahun 2018 adalah pengetahuan baik :59 responden $(98,34 \%)$, pengetahuan cukup 1 reponden $(1,67 \%)$ dan pengetahuan kurang sebanyak 0 responden.

Distribusi Frekuensi Sikap Ibu yang Memiliki Balita Dalam Pemanfaatan Posyandu Di Kampung Sri Gading Kecamatan Lubuk Dalam Kabupaten Siak Tahun 2018 adalah sikap positif 51 responden $(85 \%)$ dan sikap negative sebanyak 9 responden (15\%).

Distribusi Frekuensi Tindakan Ibu yang Memiliki Balita Dalam Pemanfaatan Posyandu Di Kampung Sri Gading Kecamatan Lubuk Dalam Kabupaten Siak Tahun 2018 adalah tindakan baik 53 responden $(88,34 \%)$ dan tindakan tidak baik 7 responden $(11,67 \%)$.

\section{Pembahasan}

\section{Pengetahuan}

Dari hasil penelitian dapat dikategorikan Baik sebanyak 59 orang $(98,34 \%)$, Cukup sebanyak 1 orang $(1,67 \%)$ dan Kurang sebanyak 0 orang $(0 \%)$. Mayoritas pengetahuan ibu yang memiliki balita dalam pemanfaatan posyandu di Kampung Sri Gading Kecamatan Lubuk Dalam Kabupaten Siak yang menjadi responden dalam kategori Baik, yaitu sebanyak 59 orang $(98,34 \%)$.

Menurut asumsi peneliti kurang baiknya pengetahuan responden berkaitan dengan pendidikan terakhir. Hasil Penelitian berdasarkan pendidikan terakhir mayoritas responden berada pada pendidikan SD yaitu sebanyak 9 orang (15\%), SMP sebanyak 16 orang $(26,67 \%)$, SMA sebanyak 27 orang $(45 \%)$ dan PT sebanyak 8 orang $(13,34 \%)$.

Penelitian ini sejalan dengan penelitian yang dilakukan oleh Meuthya Aulia Dodhy Putri tahun 2015 dengan judul penelitian "Hubungan Faktor Perilaku Ibu Balita Dengan Kunjungan Ke Posyandu Di Wilayah Kerja Puskesmas Mokoau Tahun 2015" dari hasil analisis tergolong tingkat pengetahuan ibu yang pengetahuan kurang berjumlah 54 responden lebih tinggi $(54,0 \%)$ dibandingkan yang cukup berjumlah 46 responden $(46,0 \%)$. Hal ini dikarenakan sebagian besar responden mempunyai tingkat pendidikan menengah keatas, sehingga berpengaruh terhadap tingkat pengetahuan yang dimiliki responden, dimana pendidikan menengah cenderung memiliki pengetahuan yang baik. Pengetahuan merupakan hasil dari tahu, dan ini terjadi jika seseorang melakukan penginderaan terhadap suatu obyek tertentu (Notoadmodjo,2011).

\section{Sikap}

Dari hasil penelitian dapat dikategorikan Positif sebanyak 51 orang (85\%), Negatif sebanyak 9 orang (15\%). Mayoritas sikap ibu yang memiliki balita dalam pemanfaatan posyandu di Kampung Sri Gading 
Kecamatan Lubuk Dalam Kabupaten Siak yang menjadi responden dalam kategori Positif sebanyak 51 orang (85\%).

Menurut asumsi peneliti kurang baiknya sikap responden berkaitan dengan pekerjaan responden. Hasil Penelitian berdasarkan pekerjaan mayoritas responden berada pada pekerjaan IRT sebanyak 47 orang $(78,34 \%)$, petani sebanyak 1 orang $(1,67 \%)$, guru sebanyak $9(15 \%)$, wiraswasta sebanyak 3 orang $(5 \%)$.

Penelitian ini sejalan dengan penelitian yang dilakukan oleh Meuthya Aulia Dodhy Putri tahun 2015 dengan judul penelitian "Hubungan Faktor Perilaku Ibu Balita Dengan Kunjungan Ke Posyandu Di Wilayah Kerja Puskesmas Mokoau Tahun 2015" dari hasil analisis tergolong negatif lebih tinggi berjumlah 58 responden $(58,0 \%)$ dibandingkan yang positif berjumlah 42 responden $(42,0 \%)$. Hal ini dikarenakan sebagian besar responden mempunyai tingkat pekerjaan IRT, sehingga berpengaruh terhadap sikap yang dimiliki responden, dimana pekerjaan IRT cenderung memiliki sikap yang positif. Sikap atau attitude adalah reaksi emosional terhadap reaksi dari stimulus atau respon sosial yang merupakan predisposisi tindakan atau perilaku (Mubarak, 2012).

\section{Tindakan}

Dari hasil penelitian dapat dikategorikan Baik sebanyak 53 orang $(88,34 \%)$, Tidak Baik sebanyak 7 orang $(11,67 \%)$. Mayoritas tindakan ibu yang memiliki balita dalam pemanfaatan posyandu di Kampung Sri Gading Kecamatan Lubuk Dalam Kabupaten Siak yang menjadi responden dalam kategori Baik sebanyak 53 orang $(88,34 \%)$.

Menurut asumsi peneliti kurang baiknya tindakan responden berkaitan dengan sumber informasi responden. Hasil Penelitian berdasarkan sumber informasi mayoritas responden berada pada kategori pelayanan kesehatan sebanyak 11 orang
$(18,34 \%)$, petugas puskesmas sebanyak 48 orang $(80 \%)$, penyuluhan tenaga kesehatan sebanyak ) orang ()\%), televisi sebanyak 0 orang $(0 \%)$, majala/koran sebanyak 1 orang $(1,67 \%)$, dll sebanyak 0 orang $(0 \%)$.

Penelitian ini sejalan dengan penelitian yang dilakukan oleh Meuthya Aulia Dodhy Putri tahun 2015 dengan judul penelitian "Hubungan Faktor Perilaku Ibu Balita Dengan Kunjungan Ke Posyandu Di Wilayah Kerja Puskesmas Mokoau Tahun 2015" dari hasil analisis tergolong baik lebih tinggi berjumlah 58 responden $(58,0 \%)$ dibandingkan yang tidak baik berjumlah 42 responden $(42,0 \%)$. Hal ini dikarenakan sebagian besar responden mempunyai tingkat informasi dari petugas puskesmas, sehingga berpengaruh terhadap tindakan yang dimiliki responden, dimana informasi dari petugas puskesmas cenderung memiliki tindakan yang baik. Tindakan (practice) merupakan aktifitas fisik yang mencerminkan kemampuan motorik dalam psikomotor seseorang (Mubarak, 2011).

\section{SIMPULAN}

1.Pengetahuan baik sebanyak 59 responden yakni $(98,34 \%)$

2.Sikap positif sebanyak 51 responden $(85 \%)$

3.Tindakan baik sebanyak 53 responden $(88,34 \%)$.

\section{DAFTAR PUSTAKA}

Adnani, H. 2011. Ilmu Kesehatan Masyarakat. Nuha Medika, Yogyakarta

Kemenkes RI. Buku Panduan Kader Posyandu Menuju Keluarga Sadar Gizi. Jakarta Direktorat Bina Gizi Kementerian Kesehatan R.I; (2011)

Kemenkes RI. 2012. Ayo ke Posyandu Setiap Bulan.Jakarta: Pusat Promosi Kesehatan Kementerian Kesehatan RI. Mubarak, Wahit Iqbal. Dkk. 2012. Promosi Kesehatan. Graha Ilmu: Yogyakarta 
Nadra, Raihana Alkaff, Minsarnawati. 2012. Psikologi kesehatan bagi praktisi kesehatan masyarakat. Jakarta; FKIK UIN Jakarta

Notoatmodjo, S. 2011. Kesehatan Masyarakat Ilmu dan Seni Edisi Revisi 2011. Jakarta: Rineka Cipta.

Notoatmodjo, Soekidjo 2011. Kesehatan Masyarakat : Ilmu dan Seni ( Edisi Revisi 2011), Rineka Cipta, Jakarta

Olanrewajhu, Raphael Babatunde dkk. 2011. Prevalence and Determinants of Malnutrition among Under-five Children of Farming Households in Kwara State, Nigeria. Journal of Agricultural Science

Riskesdas, 2014. Kesehatan anak. Jakarta : Kementrian Kesehatan RI

Susilo R, 2011, Pendidikan kesehatan dalam keperawatan, Nuha Medika, Yogyakarta

Suharti, Erni. 2012. Hubungan faktor pengetahuan, sikap, dan dukungan keluarga dengan perilaku kunjungan ke posyandu pada ibu bekerja di Banjanegara Jawa Tengah. Fakultas Kesehatan Masyarakat Universitas Indonesia

Hasanah, Jumiatun Indah. 2015. Faktor faktor yang mempengaruhi Pemanfaatan Pelayanan Posyandu Di Wilayah Kerja Puskesmas Rorotan
2015. FKM Universitas Sumatera Utara

Dinkes Sultra. 2012. Profil Kesehatan Sulawesi Tenggara 2012. Kendari.

Puskesmas Mokoau. 2015. Profil Puskesmas Mokoau. Kendari.

Notoatmodjo. 2003. Ilmu Kesehatan Masyarakat. Jakarta : Rineka Cipta.

Aprianti, L. 2013. Perbedaan Rata-Rata Partisipasi Ibu Balita Berdasarkan Letak Wilayah Posyandu di Puskesmas Kelurahan Duri Kepa Tahun 2013.

Skripsi. Program Studi Ilmu Gizi. Universitas Esa Unggul. Jakarta.

Suryaningsih, H. (2012) Faktor-faktor yang berhubungan dengan perilaku kunjungan ibu bayi dan balita ke posyandu di Puskesmas Kemiri Muka Kota Depok tahun 2012. Skripsi. Program Sarjana Kesehatan Masyarakat. Universitas Indonesia. Jakarta.

Novianti Susi (2012) Faktor - faktor yang Berhubungan dengan Perilaku Pemanfaatan Posyandu Oleh Oleh Ibu Balita Di Wilayah Kerja Puskesmas Maek Kabupaten Lima Puluh Kota. Bandung

Putri Meuthy, AD (2015) Hubungan Faktor Perilaku Ibu Balita dengan Kunjungan Ke Posyandu Di Wilayah Kerja Puskesmas Mokoau. Surabaya. 